\title{
Effects of alprostadil and iloprost on renal, lung, and skeletal muscle injury following hindlimb ischemia-reperfusion injury in rats
}

This article was published in the following Dove Press journal:

Drug Design, Development and Therapy

19 August 2016

Number of times this article has been viewed

\author{
Dilek Erer ${ }^{1, *}$ \\ Abdullah Özer ${ }^{1, *}$ \\ Hüseyin Demirtaș' \\ İpek Ișık Gönül² \\ Halil Kara ${ }^{3}$ \\ Hande Arpaci ${ }^{4}$ \\ Faruk Metin Çomu ${ }^{5}$ \\ Gürsel Levent Oktar' \\ Mustafa Arslan ${ }^{6}$ \\ Ayșegül Küçük ${ }^{7}$ \\ 'Department of Cardiovascular \\ Surgery, ${ }^{2}$ Department of Pathology, \\ Gazi University Medical Faculty, \\ ${ }^{3}$ Department of Pharmacology, \\ Yıldırım Beyazıt University Medical \\ Faculty, ${ }^{4}$ Department of Oral \\ and Maxillofacial Surgery, Ankara \\ University Faculty of Dentistry, \\ Besevler, Ankara, ${ }^{5}$ Department of \\ Physiology, Kırıkkale University \\ Medical Faculty, Kırıkkale, \\ ${ }^{6}$ Department of Anesthesiology and \\ Reanimation, Gazi University Medical \\ Faculty, Ankara, ${ }^{7}$ Department of \\ Physiology, Dumlupınar University \\ Medical Faculty, Kütahya, Turkey \\ *These authors contributed equally \\ to this work
}

Objectives: To evaluate the effects of alprostadil (prostaglandin [PGE1] analog) and iloprost (prostacyclin [PGI2] analog) on renal, lung, and skeletal muscle tissues after ischemia reperfusion (I/R) injury in an experimental rat model.

Materials and methods: Wistar albino rats underwent 2 hours of ischemia via infrarenal aorta clamping with subsequent 2 hours of reperfusion. Alprostadil and iloprost were given starting simultaneously with the reperfusion period. Effects of agents on renal, lung, and skeletal muscle (gastrocnemius) tissue specimens were examined.

Results: Renal medullary congestion, cytoplasmic swelling, and mean tubular dilatation scores were significantly lower in the alprostadil-treated group than those found in the $\mathrm{I} / \mathrm{R}$-only group ( $P<0.0001, P=0.015$, and $P<0.01$, respectively). Polymorphonuclear leukocyte infiltration, pulmonary partial destruction, consolidation, alveolar edema, and hemorrhage scores were significantly lower in alprostadil- and iloprost-treated groups $(P=0.017$ and $P=0.001 ; P<0.01$ and $P<0.0001)$. Polymorphonuclear leukocyte infiltration scores in skeletal muscle tissue were significantly lower in the iloprost-treated group than the scores found in the nontreated I/R group $(P<0.0001)$.

Conclusion: Alprostadil and iloprost significantly reduce lung tissue I/R injury. Alprostadil has more prominent protective effects against renal I/R injury, while iloprost is superior in terms of protecting the skeletal muscle tissue against I/R injury.

Keywords: alprostadil, iloprost, ischemia reperfusion injury, rat, renal, lung, skeletal muscle

\section{Introduction}

Ischemia reperfusion ( $\mathrm{I} / \mathrm{R})$ injury during abdominal aortic aneurysm reconstructions and aortoiliac disease operations is a consequence of clamping and subsequent declamping of the infrarenal aorta. ${ }^{1}$ Clamping (ischemia period) and declamping (reperfusion period) the aorta result in both local tissue (muscle tissue, distal regions of clamped aorta) effects and distant organ injury which includes kidney, lung, brain, heart, and other organs..$^{2-4}$ Renal failure incidence after aorta surgery is reported to be between 0.7 and 8.8 , while mortality rates are reported to be between $50 \%$ and $90 \%$ after renal replacement therapy. ${ }^{5,6}$ Pulmonary failure after acute renal failure results in high morbidity and mortality. ${ }^{7} \mathrm{I} / \mathrm{R}$ injury and systemic inflammatory response syndrome may lead to acute respiratory distress and/or noncardiogenic pulmonary edema. ${ }^{8}$ Mortality rates is high as $80 \%$ of acute renal injury is complicated with acute respiratory failure. ${ }^{9}$

Alprostadil is a prostaglandin-analog drug (PGE1) and a derivative of dihomog-linoleic acid; it has anti-inflammatory, potent vasodilatory, collagenase inhibitor
Correspondence: Mustafa Arslan Department of Anesthesiology and Reanimation, Gazi University Medical Faculty, Besevler, 065I0, Ankara, Turkey Tel +90312 2026739

Email mustarslan@gmail.com 
activities with the inhibition of in vitro platelet aggregation, thromboxane secretion, and proliferation of vascular smooth muscle cells. ${ }^{10}$ PGE1 exerts protective effects against ischemia of oxygen and glucose in ischemic cells. ${ }^{11}$ Several studies demonstrated protective effects of alprostadil against I/R injury of different organs and tissues such as lung, kidney, heart, brain, and skeletal muscle. ${ }^{12,13}$

Iloprost is an analog of prostacyclin; PGI2 has important properties including inhibition of platelet aggregation, vasodilation, inhibition of leukocyte activation, and cytoprotection achieved by decreasing the inflammatory reaction following I/R injury. ${ }^{14-16}$ Also, iloprost inhibits the release of endothelin-1, tumor necrosis factor- $\alpha$, and soluble adhesion molecules and also the production of growth factors such as transforming growth factor and connective tissue growth factor. ${ }^{17,18}$ Pulmonary arterial hypertension, ischemic episodes of Raynaud's phenomenon, scleroderma and systemic sclerosis, ${ }^{19}$ peripheral vascular disease, and diabetic foot are main areas of iloprost usage. Besides clinical usage, protective roles of iloprost on I/R injury of different tissues have been demonstrated. ${ }^{20,21}$

In this study, the effects of alprostadil and iloprost on kidney, lung, and skeletal muscle tissues after I/R injury secondary to infrarenal aorta clamping and declamping were investigated.

\section{Materials and methods}

\section{Animals and experimental protocol}

This study was conducted in the Physiology Laboratory of Kirikkale University with consent from the Experimental Animals Ethics Committee of Gazi University. All of the procedures were performed according to accepted standards of the International Guide for the Care and Use of Laboratory Animals.

In this study, 24 Wistar Albino rats weighing between 200 and $250 \mathrm{~g}$, raised under similar environmental conditions, were used. The rats were kept under $20^{\circ} \mathrm{C}-21^{\circ} \mathrm{C}$ at cycles of 12-hour daylight and 12-hour darkness and had free access to food until 2 hours before the anesthesia procedure. The animals were randomly separated into four groups, each containing six rats. Midline laparotomy was performed under ketamine anesthesia.

\section{Control group}

Midline laparotomy was done alone without any additional surgical intervention. Animals in the control group remained under surgery similar to animals in other study groups (4 hours); they were then sacrificed and renal, lung, and skeletal muscle tissue specimens were collected for histopathological investigation.

\section{I/R group}

Midline laparotomy was done in a similar manner. The infrarenal segment of the aorta was clamped for 2 hours. After removing the clamp, reperfusion was established for another 2 hours. Finally, all rats received ketamine $100 \mathrm{mg} \mathrm{kg}{ }^{-1}$ intraperitoneally and sacrificed; renal, lung, and skeletal muscle tissue specimens were collected for histopathological investigation.

\section{I/R group with alprostadil}

Similar steps were followed, but in addition to the aforementioned procedure, alprostadil was given $\left(20 \mathrm{mcg} \mathrm{kg}^{-1}\right)$ intravenously (via tail vein) and simultaneously with the reperfusion period. Rats were sacrificed at the end of reperfusion period and subsequently renal, lung, and skeletal muscle tissue specimens were collected for histopathological investigation.

\section{I/R group with iloprost}

Similar steps were followed but in addition to the aforementioned procedure, iloprost was given $\left(10 \mathrm{mcg} \mathrm{kg}^{-1}\right)$ intravenously (via tail vein) and simultaneously with the reperfusion period. Rats were sacrificed at the end of the reperfusion period, and subsequently renal, lung, and skeletal muscle tissue specimens were collected for histopathological investigation.

\section{Histopathological examination}

Tissue samples (skeletal muscle [gastrocnemius], renal, and lung) were identified, sliced, and immersed in $10 \%$ buffered formalin solution, and then dehydrated and embedded in paraffin for 24 hours. Subsequently, tissue sections of $4 \mu \mathrm{m}$ were mounted on slides for staining with hematoxylin and eosin.

Acute renal injury was evaluated based on the presence or absence of interstitial capillary congestion, interstitial inflammation, tubular dilatation, swelling of tubular epithelium (ballooning of cytoplasm), and tubular necrosis. Medullary congestion was scored semiquantitatively as follows: (0) no congestion or negligible congestion (congestion identified in original magnification $\times 400$ ), (1) mild (identified in original magnification $\times 200$ ), (2) moderate (identified in original magnification $\times 100$ ), and (3) severe (identified in original magnification $\times 40$ ). Renal injury was scored semiquantitatively using the extent of affected (confirmed with the presence of tubular necrosis, swelling of tubular epithelium [ballooning of cytoplasm], tubular dilatation, and interstitial inflammation) parenchymal area as follows: (0) no injury, (1) mild $<25 \%$, (2) moderate between $25 \%$ and $50 \%$, and $(3)$ severe $>50 \%$. 
Table I Scores obtained from light microscopy of kidney tissues (mean \pm standard deviation)

\begin{tabular}{llllll}
\hline & $\begin{array}{l}\text { Group C } \\
(\mathbf{n}=\mathbf{6})\end{array}$ & $\begin{array}{l}\text { Group IR } \\
(\mathbf{n}=\mathbf{6})\end{array}$ & $\begin{array}{l}\text { Group IR-A } \\
(\mathbf{n}=\mathbf{6})\end{array}$ & $\begin{array}{l}\text { Group IR-I } \\
(\mathbf{n}=\mathbf{6})\end{array}$ \\
\hline Medullary congestion & $0.33 \pm 0.21^{*}$ & $1.67 \pm 0.49$ & $0.00 \pm 0.00^{*}$ & $1.16 \pm 0.61$ & 0.032 \\
Tubular necrosis & $0.00 \pm 0.00$ & $0.00 \pm 0.00$ & $0.00 \pm 0.00$ & $0.00 \pm 0.00$ & - \\
Cytoplasmic swelling & $0.00 \pm 0.00^{*}$ & $0.67 \pm 0.33$ & $0.00 \pm 0.00 *$ & $0.17 \pm 0.17$ & 0.045 \\
Tubular dilatation & $0.00 \pm 0.00^{*}$ & $0.50 \pm 0.22$ & $0.00 \pm 0.00^{*}$ & $0.00 \pm 0.00^{*}$ & 0.010 \\
Inflammation & $0.17 \pm 0.17$ & $0.50 \pm 0.22$ & $0.33 \pm 0.21$ & $0.33 \pm 0.21$ & 0.724 \\
\hline
\end{tabular}

Notes: **Significance level with Kruskal-Wallis test, $P<0.05$. $* P<0.05$ compared with Group IR. Group $C$ is the Control Group, Group IR is the Ischemia Reperfusion Group, Group IR-A is the Ischemia Reperfusion Group treated with Alprostadil, Group IR-I is the Ischemia Reperfusion Group Treated with Iloprost.

Following histological preparation of specimens as explained earlier, lung injury was scored semiquantitatively using the extent of affected (confirmed with the presence of several parameters including the enlargement of interalveolar septum and congestion, neutrophilic infiltration, perivascular alveolar edema, alveolar hemorrhage, and partial pulmonary destruction) parenchymal areas as follows: (0) no significant change, (1) mild pulmonary injury (mild to moderate interstitial congestion accompanied by mild neutrophilic infiltration), (2) moderate neutrophilic infiltration, perivascular edema, and partial destruction on lung parenchyma, (3) complete pulmonary destruction accompanied by severe neutrophilic infiltration.

Specimens of rat skeletal muscle tissue were prepared using the same method as mentioned earlier in the first paragraph of the histopathological examination section, and tissue injury was scored semiquantitatively as follows: (0) no injury, (1) mild, (2) moderate, and (3) severe. Injury was evaluated with respect to the following parameters: disorganization of muscle fibers, degeneration, necrosis, inflammatory cell infiltration, and interstitial edema were used to evaluate tissue injury. All parameters were scored semiquantitatively using the extent of affected parenchymal areas as follows: (0) normal, (1) mild, (2) moderate, and (3) severe.

\section{Statistical analysis}

The statistical analyses were performed with SPSS 17.0 software program (SPSS Inc., Chicago, IL, USA), and $P<0.05$ was considered statistically significant. The findings were expressed as mean \pm standard deviation. The data were evaluated with Kruskal-Wallis variance analysis. The variables with significance were evaluated with Bonferroni corrected Mann-Whitney $U$-test.

\section{Results}

Significant differences were found between groups in terms of renal medullary congestion, cytoplasmic swelling, and tubular dilatation $(P=0.032, P=0.045$, and $P=0.010$, respectively). Medullary congestion scores were significantly lower in Group C (control group) and Group IR-A (I/R group with alprostadil) than in Group IR ( $P=0.023, P<0.0001$ respectively). Similarly, cytoplasmic swelling scores were higher for those in Group IR than for those in Group C and Group IR-A ( $P=0.015)$. Mean tubular dilatation scores were significantly lower in all groups than those in Group IR (Table 1, Figure 1).

Significant differences were found between groups in terms of polymorphonuclear leukocyte (PMNL) infiltration, alveolar edema, hemorrhage, pulmonary partial destruction, and consolidation $(P=0.002, P=0.010, P<0.0001$, respectively). PMNL infiltration scores obtained in Group C, Group IR-A, and Group IR-I were significantly lower than those in Group IR ( $P<0.0001, P=0.017, P=0.001$, respectively). Similarly, pulmonary partial destruction and consolidation scores in Group C, Group IR-A, and Group IR-I (I/R group with iloprost) were significantly lower than those in Group IR $(P<0.0001)$. Alveolar edema and hemorrhage were significantly higher in Group IR than those in other study groups (Table 2, Figure 2).

Significant differences were found between polymorphonuclear cell infiltration scores in skeletal muscle tissue specimens of groups $(P=0.002)$. PMNL infiltration scores were significantly lower in Group C and Group IR-I than scores found in Group IR $(P<0.0001)$ (Table 3, Figure 3).

\section{Discussion}

We investigated the effects of two prostaglandin analogs (alprostadil [PGE1] and iloprost [PGI2]) on three different tissues/organs after an experimental $\mathrm{I} / \mathrm{R}$ injury model that included clamping and subsequent declamping of the infrarenal aorta. To the best of our knowledge, this is the first study investigating the effects of these agents on different tissues/organs in a single experimental design.

\section{Effects of alprostadil and iloprost on renal tissue after I/R injury}

We found that alprostadil had significant protective effects after I/R injury which were proved by lower medullary congestion, cytoplasmic swelling, and tubular dilatation 

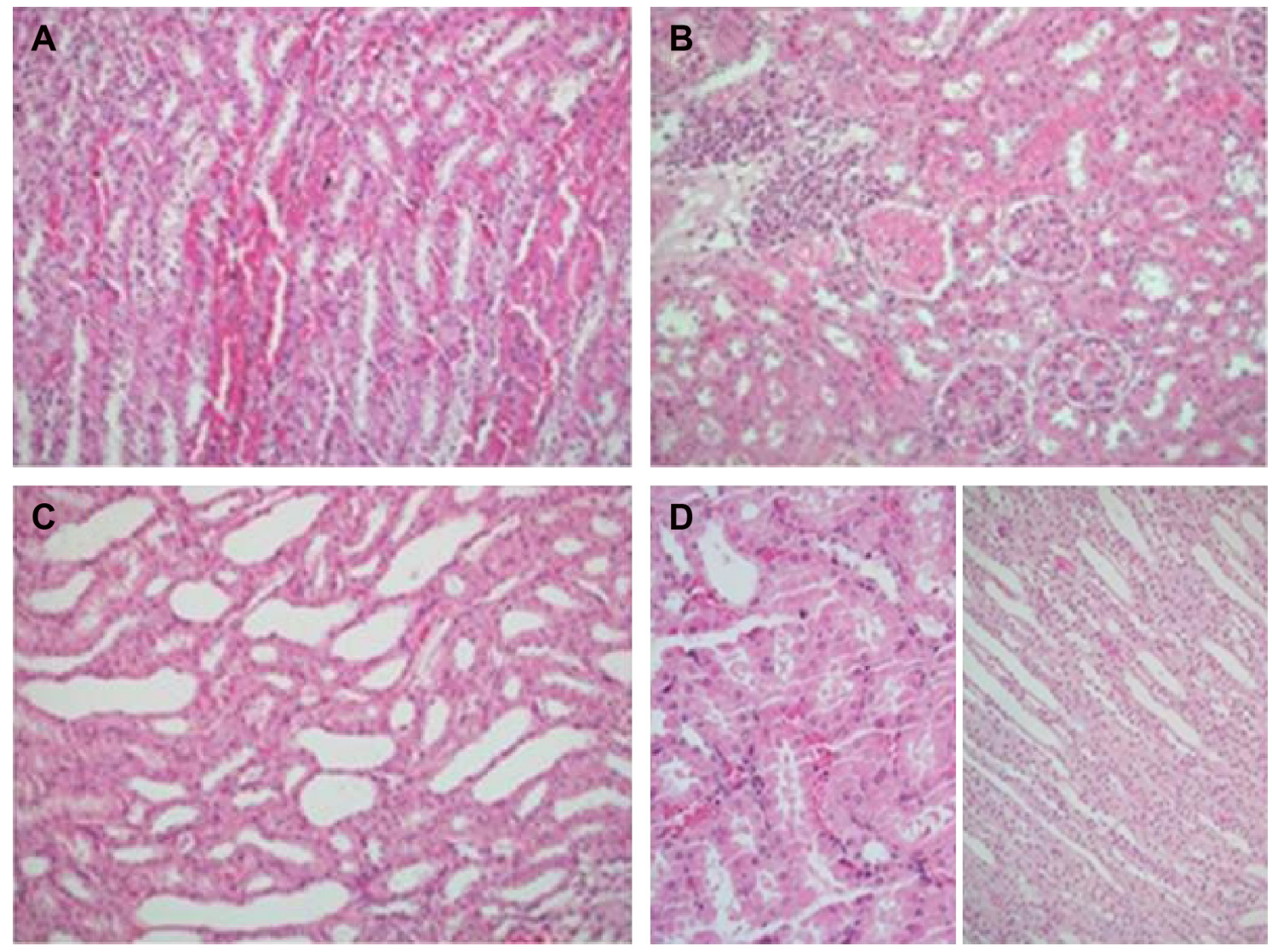

Figure I Nephrectomy specimens of four groups.

Notes: (A) Medullary congestion in the control group; (B) renal cortical parenchyma with leucocytic infiltration, interstitial edema, and prominent congestion with acute tubular injury in the ischemia reperfusion (IR) group; (C) tubular dilatation without any obvious acute injury in the renal parenchyma of the IR-A group; (D) Mild cortical congestion without any remarkable pathology in either the cortical or the medullary kidney parenchyma of the IR-I group.

scores found in the Alprostadil-treated group (IR-A) when compared with Group IR $(P<0.0001, P=0.015$, and $P=0.01$, respectively). Alprostadil is an exogenous form of PGE1, and several studies have shown positive effects of alprostadil on renal hemodynamics and perfusion. ${ }^{1,22,23}$ Renal vasodilation and improved renal artery perfusion are possible mechanisms underlying the protective effects of alprostadil on the renal tissue. ${ }^{1,23} \mathrm{Xu}$ et $\mathrm{a}^{22}$ found protective effects of alprostadil when combined with hydration in patients with contrastinduced nephropathy, and they concluded that this finding is a consequence of vasodilatory and perfusion-improving effects of alprostadil. Soares et al ${ }^{24}$ conducted a study with a similar design as that of our study except for shorter ischemia and reperfusion periods ( 30 minutes/ 1 hour vs 2 hours/ 2 hours). They found lower expressions of Intracellular Adhesion Molecule 1 (ICAM-1) and tissue architecture disarrangement in the alprostadil-treated group. Additionally, they found less leukocyte tubular adhesion and tissue necrosis in the alprostadil-treated group. They concluded that the protective effect of alprostadil could be implemented through

Table 2 Scores obtained from light microscopy of lung tissues (mean \pm standard deviation)

\begin{tabular}{llllll}
\hline & $\begin{array}{l}\text { Group C } \\
(\mathbf{n}=\mathbf{6})\end{array}$ & $\begin{array}{l}\text { Group IR } \\
(\mathbf{n}=\mathbf{6})\end{array}$ & $\begin{array}{l}\text { Group IR-A } \\
(\mathbf{n}=\mathbf{6})\end{array}$ & $\begin{array}{l}\text { Group IR-I } \\
(\mathbf{n}=\mathbf{6})\end{array}$ & $\begin{array}{l}\text { P-value** } \\
\text { Interstitial enlargement and congestion }\end{array}$ \\
\hline PMNL infiltration & $1.00 \pm 0.00$ & $1.83 \pm 0.40$ & $1.33 \pm 0.21$ & $1.33 \pm 0.33$ & 0.247 \\
Alveolar edema, hemorrhage & $1.00 \pm 0.00^{*}$ & $2.00 \pm 0.00$ & $1.50 \pm 0.22^{*}$ & $1.33 \pm 0.21^{*}$ & 0.002 \\
Intravascular thrombosis & $0.00 \pm 0.00^{*}$ & $0.50 \pm 0.22$ & $0.00 \pm 0.00^{*}$ & $0.00 \pm 0.00^{*}$ & 0.010 \\
Pulmonary partial destruction, consolidation & $0.00 \pm 0.00$ & $0.00 \pm 0.00$ & $0.00 \pm 0.00$ & $0.00 \pm 0.00$ & - \\
\hline
\end{tabular}

Notes: **Significance level with Kruskal-Wallis test, $P<0.05$. $* P<0.05$ compared with Group IR. Group $C$ is the Control Group, Group IR is the Ischemia Reperfusion Group, Group IR-A is the Ischemia Reperfusion Group treated with Alprostadil, Group IR-I is the Ischemia Reperfusion Group Treated with lloprost.

Abbreviation: PMNL, polymorphonuclear leukocyte. 

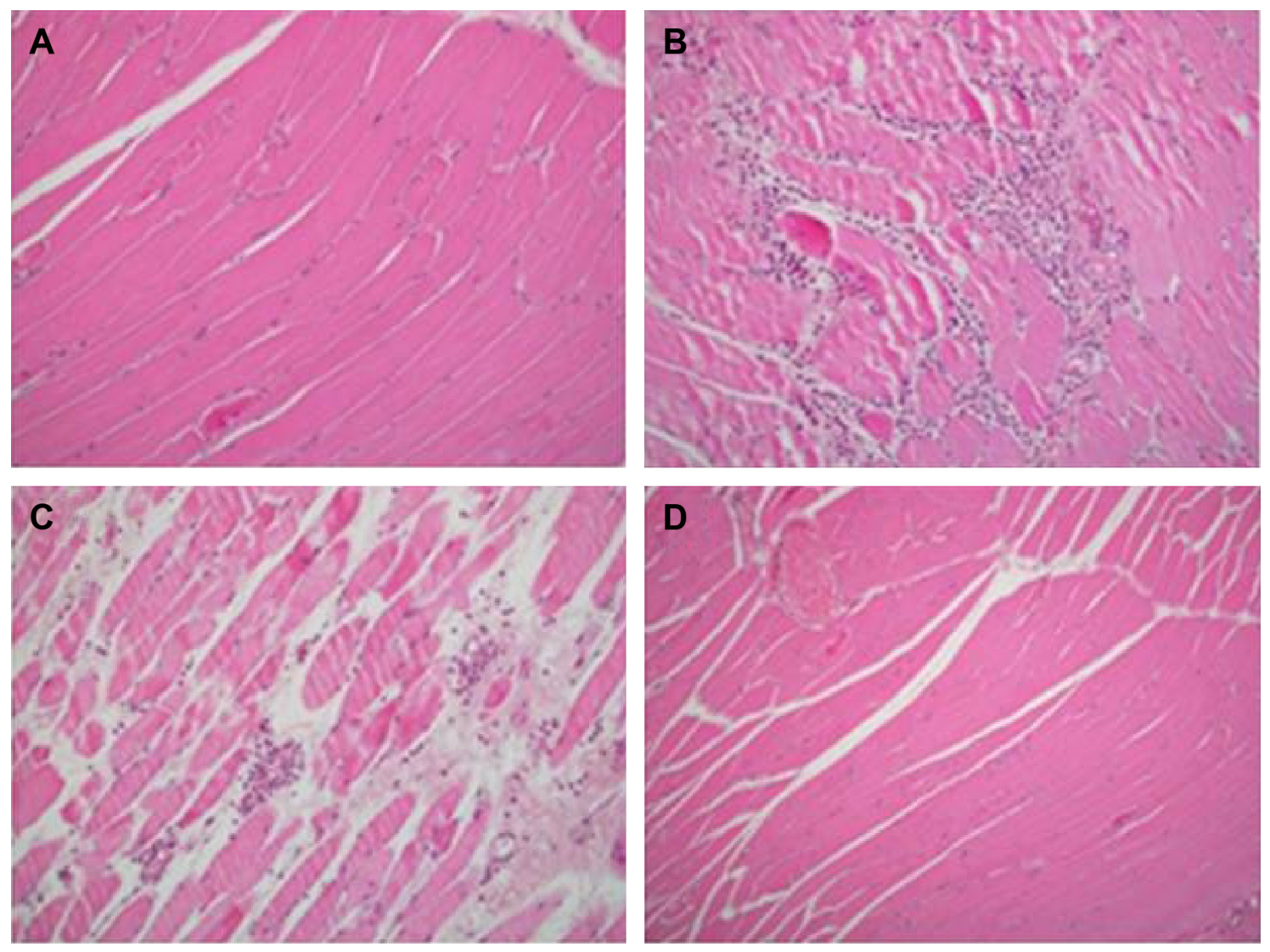

Figure 2 Lung parenchyma of four groups.

Notes: (A) Mild interalveolar septal congestion in the control group; (B) parenchymal consolidation characterized by prominent congestion and leucocytic infiltration in the ischemia reperfusion (IR) group; (C) and (D) thickened interalveolar septa with congestion and mild leucocytic infiltration in the IR-A group and IR-I group.

anti-inflammatory routes such as inhibiting the expression of ICAM-1 and other inflammatory parameters. Although the expression or levels of inflammatory parameters have not been investigated, histological findings of our study are correlated with the study conducted by Soares et al. ${ }^{24}$

Iloprost produced less promising findings regarding renal tissue protection that presented with only lower tubular dilatation scores when compared with the $\mathrm{I} / \mathrm{R}$ group. Contrary to our results, Sahsivar et $\mathrm{l}^{14}$ found protective effects of iloprost documented with all histological parameters including focal glomerular necrosis, dilatation of Bowman capsule, degeneration of tubular epithelium, necrosis in tubular epithelium, and tubular dilatation. In a study conducted by Sahsivar et al, ${ }^{14}$ iloprost was given as continuous intravenous infusion of $20 \mathrm{ng} \mathrm{kg} / \mathrm{min}$ during 60 minutes of ischemia and 120 minutes of reperfusion via tail vein, whereas in our study, iloprost was given at $10 \mathrm{mcg} \mathrm{kg}^{-1}$ dose through the tail vein for 30 minutes starting simultaneously with the reperfusion period. So we suggest that differences in the iloprost dose, infusion time, and starting of drug therapy may affect the results of studies.

\section{Effects of alprostadil and iloprost on lung tissue after $I / R$ injury}

We found that alprostadil and iloprost had significant protective effects against lung $\mathrm{I} / \mathrm{R}$ injury when compared with the $\mathrm{I} / \mathrm{R}$-alone group. PMNL infiltration, alveolar edema,

Table 3 Scores obtained from light microscopy of skeletal muscle tissues (mean \pm standard deviation)

\begin{tabular}{|c|c|c|c|c|c|}
\hline & $\begin{array}{l}\text { Group C } \\
(n=6)\end{array}$ & $\begin{array}{l}\text { Group IR } \\
(n=6)\end{array}$ & $\begin{array}{l}\text { Group IR-A } \\
(n=6)\end{array}$ & $\begin{array}{l}\text { Group IR-I } \\
(n=6)\end{array}$ & $P$-value** \\
\hline PMNL infiltration & $0.00 \pm 0.00 *$ & $|| 7 \pm 0.3 \mid$. & $0.83 \pm 0.31$ & $0.00 \pm 0.00 *$ & 0.002 \\
\hline Edema & $0.00 \pm 0.00$ & $0.17 \pm 0.17$ & $0.00 \pm 0.00$ & $0.00 \pm 0.00$ & 0.413 \\
\hline Myocyte disorganization, degeneration, necrosis & $0.00 \pm 0.00$ & $0.17 \pm 0.17$ & $0.00 \pm 0.00$ & $0.00 \pm 0.00$ & 0.413 \\
\hline
\end{tabular}

Notes: **Significance level with Kruskal-Wallis test, $P<0.05$. $* P<0.05$ compared with Group IR. Group C is the Control Group, Group IR is the Ischemia Reperfusion Group, Group IR-A is the Ischemia Reperfusion Group treated with Alprostadil, Group IR-I is the Ischemia Reperfusion Group Treated with Iloprost. Abbreviation: PMNL, polymorphonuclear leukocyte. 

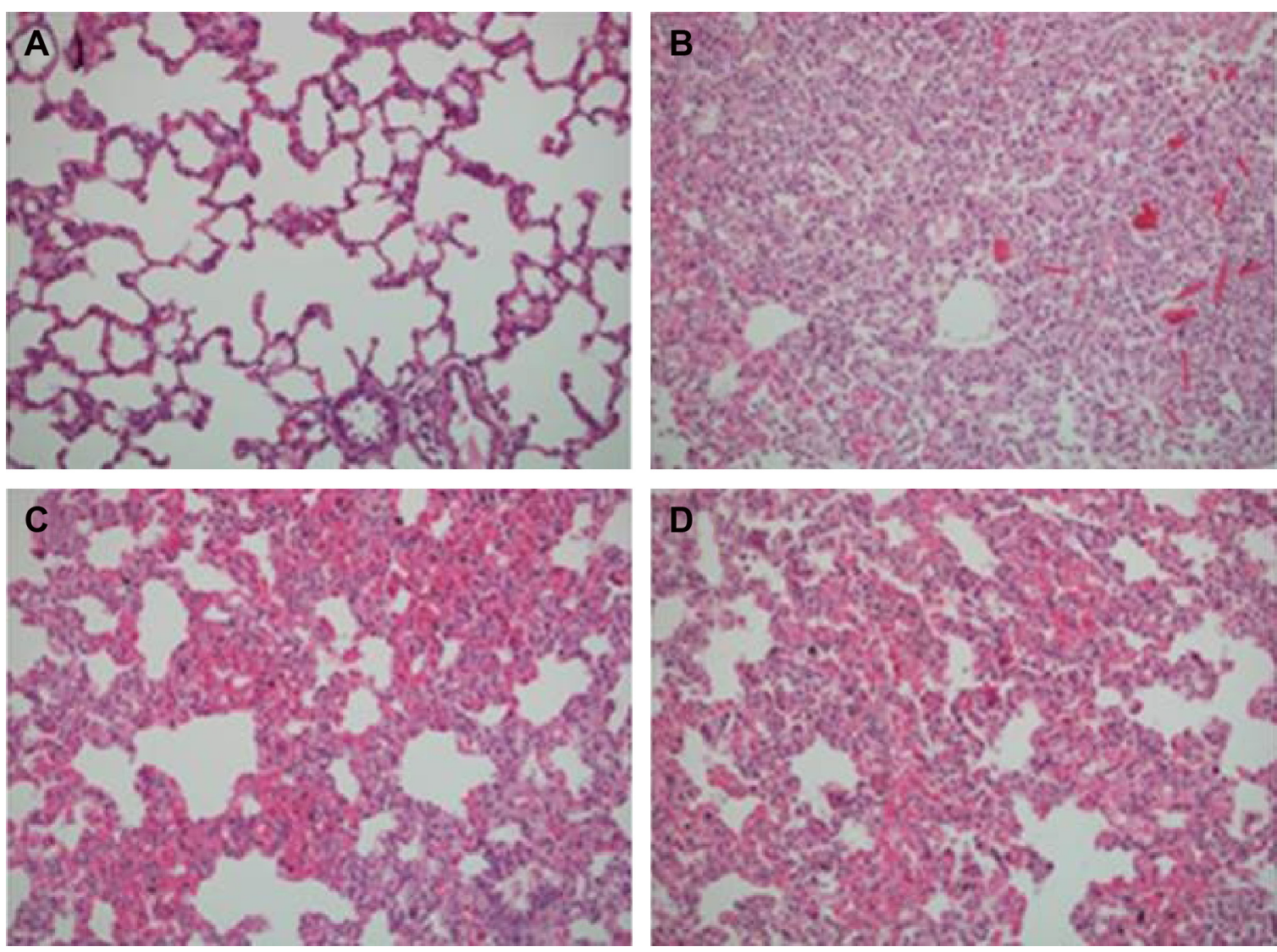

Figure 3 Skeletal muscle biopsies of four groups.

Notes: (A) Normal striated muscle in the control group; (B) polymorphonuclear leucocytic infiltration with myocyte necrosis in the ischemia reperfusion (IR) group; (C) interstitial edema and mild perivascular leucocytic infiltration in the IR-A group; (D) unremarkable striated muscle biopsy of the IR-I group.

hemorrhage, pulmonary partial destruction, and consolidation were significantly lower than those in the I/R-alone group ( $P=0.002, P=0.010, P<0.0001$, respectively). Our findings are correlated with Oztay et $\mathrm{al}^{25}$ and other different studies that showed protective effects of alprostadil on lung tissue after I/R injury. ${ }^{12,13,25}$ Oztay et $\mathrm{a}^{25}$ reported only a weak $\mathrm{I} / \mathrm{R}$ injury effect on the lung structure that presented with edema, partly dilated alveoli, and slight leukocyte infiltration. Authors suggested that this weak effect of Renal Ischemia Reperfusion on the lung structure could be related to the duration of $\mathrm{I} / \mathrm{R}$ ( 1 hour of ischemia and 1 hour of reperfusion). However, pulmonary edema induction after $\mathrm{I} / \mathrm{R}$ injury is the most common evidence obtained, ${ }^{26}$ and significant alveolar edema was accepted as sufficient finding for lung injury. In our study, the duration of I/R was longer ( 2 hours/2 hours), and so more significant lung injury findings in our study may be a consequence of longer duration of $\mathrm{I} / \mathrm{R}$ periods.

Significant protective effects of iloprost were found on the lung tissue after I/R injury. Several studies showed decreased pulmonary injury after ischemia with iloprost treatment, and this result was attributed to important properties of iloprost such as preservation of the scavenging system, inhibition of platelet aggregation, vasodilatation, and cytoprotection. ${ }^{27,28}$ Erer et $\mathrm{al}^{8}$ showed immunohistochemically and biochemically (measurement of total oxidant and antioxidant status) protective effects of iloprost using similarly designed experiments, and we think that results of histological evaluation in our study supports previous findings.

\section{Effects of alprostadil and iloprost on skeletal muscle tissue after I/R injury}

There was no difference between the alprostadil-treated group and the $\mathrm{I} / \mathrm{R}$-only group in terms of inflammatory changes in the skeletal muscle. Antonio et $\mathrm{al}^{29}$ reported that alprostadil did not reduce the release of muscular enzymes, the consumption of tissue glycogen, or the effects of ischemia and reperfusion on the cell membrane, characterized by lipid peroxidation at the end of experimental study, which was designed in the same way as our study. However, infrarenal aorta ischemia period was longer (5 hours) and reperfusion period was shorter (1 hour) than the period used in this study. In contrast, Rowlands et $\mathrm{al}^{30}$ reported improved 
skeletal muscle (gastrocnemius muscle of rats) blood flow and decreased muscle edema with alprostadil and iloprost treatment following 5.5 hours of ischemia and 4 hours during reperfusion periods. Luther et $\mathrm{al}^{31}$ demonstrated significant reduction of free oxygen radical reactions and histological findings of protective alprostadil effects on tibialis anterior muscle following 3.5 hours of ischemia and then 4 hours of reperfusion. In another study conducted in pigs, supporting evidence for the possible protective role of alprostadil was found with regard to the improvement during initial reperfusion in regional blood flow (at 60 and 90 minutes of reperfusion), glucose consumption (at 30 minutes of reperfusion), and serum potassium regulation (at 30 and 90 minutes of reperfusion). ${ }^{32}$

Contrary to findings in the alprostadil group, significantly lower PMNL infiltration was found in the iloprost-treated group when compared with Group IR only $(P<0.0001)$. This finding is correlated with previous findings in studies investigating the effects of iloprost on skeletal muscle I/R injury. ${ }^{2,30}$ It is well known that iloprost decreases vascular resistance and increases blood flow. Additionally, iloprost has strong cytoprotective and antiaggregant properties via inhibiting thrombocyte aggregation and decreasing the synthesis of adhesion molecules. Iloprost also improves microcirculation and attenuates microvascular dysfunction. Tiryakioglu et $\mathrm{al}^{2}$ found protective effects of iloprost in I/R injury of muscle tissue (gastrocnemius muscle) evidenced by a significant decrease in all injury parameters including hemorrhage, necrosis, loss of nuclei, PMNL, monocyte, and macrophage infiltration. Although significant differences were found only in PMNL infiltration, iloprost may have protective effects against I/R injury in the skeletal muscle tissue.

\section{Limitations}

First, we evaluated only histological/pathological injury findings without any biochemical and/or immunohistochemical evaluation. This may limit the effectivity of the study results. Second, limitation is related to the sample size of the study. The sample size is small to achieve a high statistical power. However, we think that future studies investigating the effects of different prostaglandin analogs on I/R injury of different tissues may benefit from the findings of this study.

\section{Conclusion}

We can conclude that both alprostadil and iloprost effectively decrease lung tissue injury following aortic cross-clampinginduced I/R injury, while alprostadil exerts more prominent protective effects against renal tissue injury. On the other hand, more significant results were achieved with iloprost treatment against skeletal muscle tissue injury. Future studies investigating the effects of alprostadil and iloprost on tissue levels and biochemical analysis after I/R injury will help to interpret these results in a better way.

\section{Disclosure}

The authors declare no conflicts of interest.

\section{References}

1. Dolegowska B, Pikuła E, Safranow K, et al. Metabolism of eicosanoids and their action on renal function during ischaemia and reperfusion: the effect of alprostadil. Prostaglandins Leukot Essent Fatty Acids. 2006; 75(6):403-411.

2. Tiryakioglu O, Erkoc K, Tunerir B, et al. The effect of iloprost and $\mathrm{N}$-acetylcysteine on skeletal muscle injury in an acute aortic ischemiareperfusion model: an experimental study. Biomed Res Int. 2015;2015: 453748 .

3. Faubel S. Acute kidney injury and multiple organ dysfunction syndrome. Minerva Urol Nefrol. 2009;61(3):171-188.

4. Li X, Hassoun HT, Santora R, Rabb H. Organ crosstalk: the role of the kidney. Curr Opin Crit Care. 2009;15(6):481-487.

5. Vemuri C, Wainess RM, Dimick JB, et al. Effect of increasing patient age on complication rates following intact abdominal aortic aneurysm repair in the United States. J Surg Res. 2004;118(1):26-31.

6. Powell RJ, Roddy SP, Meier GH, Gusberg RJ, Conte MS, Sumpio BE. Effect of renal insufficiency on outcome following infrarenal aortic surgery. Am J Surg. 1997;174(2):126-130.

7. Feltes CM, Van Eyk J, Rabb H. Distant-organ changes after acute kidney injury. Nephron Physiol. 2008;109(4):p80-p84.

8. Erer D, Dursun AD, Oktar GL, et al. The effects of iloprost on lung injury induced by skeletal muscle ischemia-reperfusion. Bratisl Lek Listy. 2014;115(7):405-410

9. Chertow GM, Christiansen CL, Cleary PD, Munro C, Lazarus JM. Prognostic stratification in critically ill patients with acute renal failure requiring dialysis. Arch Intern Med. 1995;155(14):1505-1511.

10. Fan YY, Chapkin RS. Importance of dietary gamma-linolenic acid in human health and nutrition. J Nutr. 1998;128(9):1411-1414.

11. Hotter G, Closa D, Pi F. Arachidonate metabolism in ischemiareperfusion associated with pancreas transplantation. J Lipid Mediat Cell Signal. 1994;9(2):135-143.

12. de Perrot M, Fischer S, Liu M, et al. Prostaglandin E1 protects lung transplants from ischemia-reperfusion injury: a shift from pro- to anti-inflammatory cytokines. Transplantation. 2001;72(9): 1505-1512.

13. Aoe M, Trachiotis GD, Okabayashi K, et al. Administration of prostaglandin E1 after lung transplantation improves early graft function. Ann Thorac Surg. 1994;58(3):655-661.

14. Sahsivar MO, Narin C, Kiyici A, Toy H, Ege E, Sarigül A. The effect of iloprost on renal dysfunction after renal I/R using cystatin $\mathrm{C}$ and beta2-microglobulin monitoring. Shock. 2009;32(5):498-502.

15. Grant SM, Goa KL. Iloprost. A review of its pharmacodynamic and pharmacokinetic properties, and therapeutic potential in peripheral vascular disease, myocardial ischaemia and extracorporeal circulation procedures. Drugs. 1992;43(6):889-924.

16. Kiris I, Tekin I, Yilmaz N, Sutcu R, Karahan N, Ocal A. Iloprost downregulates expression of adhesion molecules and reduces renal injury induced by abdominal aortic ischemia-reperfusion. Ann Vasc Surg. 2009;23(2):212-223.

17. Balbir-Gurman A, Braun-Moscovici Y, Livshitz V. Antioxidant status after iloprost treatment in patients with Raynaud's phenomenon secondary to systemic sclerosis. Clin Rheumatol. 2007;26(9): $1517-1521$. 
18. Mittag M, Beckheinrich P, Haustein UF. Systemic sclerosis-related Raynaud's phenomenon: effects of iloprost infusion therapy on serum cytokine, growth factor and soluble adhesion molecule levels. Acta Derm Venereol. 2001;81(4):294-297.

19. Wigley FM, Wise RA, Seibold JR, et al. Intravenous iloprost infusion in patients with Raynaud phenomenon secondary to systemic sclerosis. A multicenter, placebo-controlled, double-blind study. Ann Intern Med. 1994;120(3):199-206.

20. Yakut N, Yasa H, Bahriye Lafci B, et al. The influence of levosimendan and iloprost on renal ischemia-reperfusion: an experimental study. Interact Cardiovasc Thorac Surg. 2008;7(2):235-239.

21. Koksel O, Ozdulger A, Aytacoqlu B, et al. The influence of iloprost on acute lung injury induced by hind limb ischemia-reperfusion in rats. Pulm Pharmacol Ther. 2005;18(4):235-241.

22. Xu RH, Ma GZ, Cai ZX, Chen P, Zhu ZD, Wang WL. Combined use of hydration and alprostadil for preventing contrast-induced nephropathy following percutaneous coronary intervention in elderly patients. Exp Ther Med. 2013;6(4):863-867.

23. Sketch MH Jr, Whelton A, Schollmayer E, et al. Prevention of contrast media-induced renal dysfunction with prostaglandin E1: a randomized, double-blind, placebo-controlled study. Am J Ther. 2001;8(3): $155-162$.

24. Soares BL, de Freitas MA, Montero EF, Pitta GB, Júnior FM. Alprostadil attenuates inflammatory aspects and leucocytes adhesion on renal ischemia and reperfusion injury in rats. Acta Cir Bras. 2014;29(Suppl 2):55-60.
25. Oztay F, Kara-Kisla B, Orhan N, Yanardaq R, Bolkent S. The protective effects of prostaglandin E1 on lung injury following renal ischemiareperfusion in rats. Toxicol Ind Health. Epub 2015 Apr 16.

26. Deng J, Hu X, Yuen PS, Star RA. Alpha-melanocyte-stimulating hormone inhibits lung injury after renal ischemia/reperfusion. Am J Respir Crit Care Med. 2004;169(6):749-756.

27. Baltalarli A, Ozcan V, Bir F, et al. Ascorbic acid (vitamin C) and iloprost attenuate the lung injury caused by ischemia/reperfusion of the lower extremities of rats. Ann Vasc Surg. 2006;20(1):49-55.

28. Fantone JC, Marasco WA, Elgas LJ, Ward PA. Stimulus specificity of prostaglandin inhibition of rabbit polymorphonuclear leukocyte lysosomal enzyme release and superoxide anion production. Am J Pathol. 1984;115(1):9-16.

29. Antonio LG, Evora PR, Piccinato CE. Use of alprostadil, a stable prostaglandin E1 analogue, for the attenuation of rat skeletal muscle ischemia and reperfusion injury. Minerva Chir. 2009;64(6):559-564.

30. Rowlands TE, Gough MJ, Homer-Vanniasinkam S. Do prostaglandins have a salutary role in skeletal muscle ischaemia-reperfusion injury? Eur J Vasc Endovasc Surg. 1999;18(5):439-444.

31. Luther B, Lehmann C, Grune T, et al. [Controlled reperfusion of ischemic extremity musculature to prevent free radical induced lesions). Zentralbl Chir. 1999;124(4):336-343. [German].

32. Abdel-Rahman U, Risteski P, Klaeffling C, et al. The influence of controlled limb reperfusion with PGE1 on reperfusion injury after prolonged ischemia. J Surg Res. 2009;155(2):293-300.
Drug Design, Development and Therapy

\section{Publish your work in this journal}

Drug Design, Development and Therapy is an international, peerreviewed open-access journal that spans the spectrum of drug design and development through to clinical applications. Clinical outcomes, patient safety, and programs for the development and effective, safe, and sustained use of medicines are the features of the journal, which

\section{Dovepress}

has also been accepted for indexing on PubMed Central. The manuscript management system is completely online and includes a very quick and fair peer-review system, which is all easy to use. Visit http://www.dovepress.com/testimonials.php to read real quotes from published authors. 